Tersedia online di: http://ejournal-balitbang.kkp.go.id/index.php/jra

\title{
PERFORMA REPRODUKSI DAN PERTUMBUHAN UDANG GALAH BETINA Macrobrachium rosenbergii SETELAH PEMBERIAN HORMON MEDROXY PROGESTERON ACETAT MELALUI PAKAN
}

\author{
Fajar Anggraeni ${ }^{* * * * \#}$, Desak Made Malini ${ }^{*}$, dan Imron ${ }^{* * \mid}$ \\ ") Universitas Padjadjaran \\ Jl. Raya Bandung Sumedang KM 21, Hegarmanah, Jatinangor, Kabupaten Sumedang, Jawa Barat 45363 \\ *al Balai Riset Pemuliaan Ikan \\ Jl. Raya 2 Sukamandi, Subang 41263, Jawa Barat
}

(Naskah diterima: 23 April 2021; Revisi final: 6 Juni 2021; Disetujui publikasi: 6 Juni 2021)

\begin{abstract}
ABSTRAK
Salah satu permasalahan pada budidaya udang galah adalah keberadaan udang galah betina bertelur pada saat pembesaran. Penghambatan pema tangan gonad menggunakan hormon medroxyprogesterone acetat (MPA) yang diberikan secara injeksi pada udang galah dapat menekan indeks kematangan gonad (IKG), perkembangan gonad, dan meningkatkan laju pertumbuhan. Namun, pemberian MPA secara injeksi dapat meningkatkan stres dan kematian pada udang galah, Tujuan dari penelitian ini adalah untuk mengkaji pengaruh pemberian hormon medroxy progesteron acetat melalui pakan terhadap performa reproduksi dan pertumbuhan. Metode yang digunakan adalah metode eksperimental, desain penelitian menggunakan rancangan acak lengkap (RAL) dengan empat perlakuan dan lima kali pengulangan. Perlakuan yang diberikan adalah kontrol (hormon M PA pada konsentrasi $0 \mathrm{mg} / \mathrm{kg}$ pakan), P-1 (hormon MPA pada konsentrasi $50 \mathrm{mg} /$ kg pakan), P-2 (hormon MPA pada konsentrasi $100 \mathrm{mg} / \mathrm{kg}$ pakan), dan P-3 (hormon M PA pada konsentrasi $150 \mathrm{mg} / \mathrm{kg}$ pakan) yang diberikan pada udang galah betina selama 60 hari. Parameter yang diamati adalah kematangan gonad, egg clutch somatic index (ESI), fekunditas, kadar estradiol, laju pertumbuhan spesifik, dan sintasan. Hasil penelitian menunjukkan bahwa pemberian hormon MPA dengan konsentrasi 50, 100 dan $150 \mathrm{mg} / \mathrm{kg}$ pakan secara signifikan menghambat reproduksi dan pada konsentrasi $100 \mathrm{mg} / \mathrm{kg}$ pakan dapat meningkatkan laju pertumbuhan pada udang galah betina umur lima bulan. ESI, fekunditas dan tingkat sintasan tidak terpengaruh oleh perlakuan. Kesimpulan dari penelitian ini adalah pemberian hormon medroxy progesteron acetat melalui pakan pada konsentrasi $100 \mathrm{mg} / \mathrm{kg}$ pakan secara signifikan dapat menghambat pematangan gonad dan peningkatan pertumbuhan udang galah betina.
\end{abstract}

\section{KATAKUNCl: medroxy progesteron acetat; Macrobrachium rosenbergii; pakan; maturasi; pertumbuhan}

ABSTRACT: Reproductive performance and growth of female freshwater prawn, Macrobrachium rosenbergii after dietary administration of medroxyprogesterone acetate hormone through feed. By: Fajar Anggraeni, Desak Made Malini, and Imron

One of the problems in giant freshwater prawn farming is female prawns laying eggs during grow-out, leading to reduced somatic growth of the prawns. Inhibition of gonad maturation using medroxyprogesterone acetate (MPA) hormone via injection in giant freshwater prawns can suppress the gonad maturity index (GSI), gonad development, and increase the growth rate. However, the administration of MPA by injection could increase stress and mortality in giant freshwater prawns. The purpose of this study was to examine the application of MPA through dietary administration on the reproductive performance and growth of female giant freshwater prawns. The experiment was arranged in a completely randomized design with four treatments and five replications. Treatments of MPA at concentrations of 0 $\mathrm{mg} / \mathrm{kg}$ feed (as control), $50 \mathrm{mg} / \mathrm{kg}$ feed (P-1), $100 \mathrm{mg} / \mathrm{kg}$ feed (P-2), and $150 \mathrm{mg} / \mathrm{kg}$ feed (P-3) were supplemented in a commercial artificial feed and fed to the freshwater prawns for 60 days. Parameters of

\footnotetext{
\# Korespondensi: Universitas Padjadjaran

Jl. Raya Bandung Sumedang KM 21, Hegarmanah, Jatinangor,

Kabupaten Sumedang, Jawa Barat 45363, Indonesia

E-mail: fajar19013@ mail.unpad.ac.id
} 
gonad maturation, egg clutch somatic index (ESI), fecundity, oestradiol concentration, specific growth rate, and survival rate were measured during the research period. The result showed that MPA administration at concentrations of 50,100, and $150 \mathrm{mg} / \mathrm{kg}$ feed significantly inhibited gonad maturation, and at concentration $100 \mathrm{mg} / \mathrm{kg}$ feed increased growth of female giant freshwater prawn at five-month age. The ESI, fecundity and survival, however, were not affected by the treatment. This study concludes that the administration of medroxyprogesterone acetate hormone through feed significantly inhibited gonad maturation and increasedthe growth of female giant freshwater prawns.

\section{KEYWORDS: feed; maturation; medroxyprogesterone acetate; growth; Macrobrachium rosenbergii}

\section{PENDAHULUAN}

Udang galah merupakan salah satu jenis dari genus Macrobrachium yang menguntungkan untuk dibudayakan karena permintaan masyarakat yang tinggi baik domestik maupun internasional, resisten terhadap penyakit, mudah dibudidayakan dan biaya produksi yang relatif rendah (Jayasankar, 2018). Produksi udang galah di seluruh dunia mengalami peningkatan dari tahun ke tahun, yaitu pada tahun 2010 produksi udang galah sebanyak 217.700 ton hingga tahun 2018 sebanyak 234.400 ton (FAO, 2020). Namun, salah satu permasalahan pada budidaya udang galah adalah keberadaan udang galah betina bertelur pada saat pembesaran. Udang galah betina mencapai maturasi pada umur lima bulan dari menetas dan pada ukuran panjang standar 68,39 \pm 7,81 mm (Krettiawan $\&$ Anggraeni, 2015). Sementara itu, udang galah yang diinginkan pasar (marketable size) berukuran lebih dari $20 \mathrm{~g}$ atau dengan panjang standar lebih dari $7 \mathrm{~cm}$ (Ranjeet \& Kurup, 2011). Pakan yang dikonsumsi udang secara fisiologis akan dicerna dan digunakan untuk pertumbuhan somatik. Jika udang mengalami maturasi, maka energi dari pakan tersebut akan terbagi untuk reproduksi. Akibatnya pertumbuhan somatik terganggu sehingga ukuran udang menjadi lebih kecil dari yang diharapkan (Franco et al., 2006). Energi yang diharapkan untuk pertumbuhan pada udang galah betina dewasa digunakan untuk pembentukan telur atau untuk aktivitas reproduksi (Cavalli et al., 2001). Hal ini sangat merugikan pembudidaya udang. Penundaan kematangan gonad udang galah pada saat fase pembesaran diharapkan mampu meningkatkan pertumbuhan somatik udang galah, karena alokasi energi dari pakan tidak digunakan untuk reproduksi. Oleh karena itu, diperlukan upaya penghambatan kematangan gonad pada udang galah betina pada fase pembesaran tersebut.

Penghambatan pematangan gonad pada udang galah betina dapat dilakukan dengan pendekatan hormonal, salah satunya adalah dengan menggunakan hormon medroxyprogesterone acetat (MPA). Medroxy progesteron acetat (MPA) merupakan progestin sintetis yang telah banyak digunakan sebagai kontrasepsi injeksi dan oral, serta sebagai terapi untuk kanker payudara dan penggantian hormon pada manusia. Progestin alami pada ikan betina berperan penting pada proses oogenesis (Nagahama \& Yamashita, 2008). MPA yang diberikan secara injeksi pada udang galah dengan dosis premix MPA $150 \mathrm{mg} / 3$ $\mathrm{mL} / \mathrm{ekor}$ udang dan dopamin $10^{-10} \mathrm{~mol} / \mathrm{ekor}$ udang dapat menekan indeks kematangan gonad (IKG), perkembangan gonad, dan meningkatkan Iaju pertumbuhan udang (Wijaya et al., 2020). Namun, pemberian MPA secara injeksi dapat meningkatkan stres dan kematian pada udang galah. Oleh karena itu, perlu dicari metode aplikasi MPA yang efektif menekan kematangan gonad dan dapat menurunkan mortalitas. Salah satu alternatifnya adalah pemberian MPA melalui pakan. Penelitian ini bertujuan untuk mengetahui pengaruh pemberian hormon MPA melalui pakan terhadap performa reproduksi udang galah betina pada fase pembesaran.

\section{BAHAN DAN METODE}

\section{Waktu dan Lokasi Penelitian}

Penelitian pengujian pengaruh pemberian hormon medroxy progesteron acetat melalui pakan terhadap performa reproduksi udang galah betina dilaksanakan di Balai Riset Pemuliaan Ikan, Kabupaten Subang, Jawa Barat pada bulan September hingga November 2020.

\section{Hewan Uji}

Hewan uji yang digunakan adalah udang galah betina strain G-I Macro-II hasil pemuliaan Balai Riset Pemuliaan Ikan (Khasani et al., 2018) berumur lima bulan dengan bobot 9,66 $\pm 1,48 \mathrm{~g}$; mempunyai organ yang lengkap dan sehat.

\section{Desain Penelitian}

Penelitian ini dilakukan dengan metode eksperimental. Rancangan yang digunakan dalam penelitian ini adalah rancangan acak lengkap (RAL) dengan empat perlakuan dan lima ulangan. Perlakuan berupa pemberian hormon medroxy progesteron acetat yang ditambahkan ke dalam pakan dengan konsentrasi $0 \mathrm{mg} / \mathrm{kg}$ pakan sebagai kontrol $(\mathrm{K}), 50$ $\mathrm{mg} / \mathrm{kg}$ pakan (P-1), $100 \mathrm{mg} / \mathrm{kg}$ pakan (P-2), dan 150 $\mathrm{mg} / \mathrm{kg}$ pakan (P-3). Perlakuan diberikan selama 60 hari. Wadah yang digunakan berupa akuarium berukuran 40 $\mathrm{cm} \times 60 \mathrm{~cm} \times 40 \mathrm{~cm}$ (lebar x panjang x tinggi) sebanyak 
20 unit yang dilengkapi dengan filter air. Akuarium yang telah diisi air diberi sekat dari kawat untuk menghindari terjadinya perilaku kanibal. Penebaran udang dilakukan di dalam akuarium penelitian dengan padat tebar sebanyak 10 ekor per akuarium dan diak limatisasi selama tiga hari. Pakan yang digunakan pada pengujian ini adalah pakan tenggelam ukuran 1,6 x 1-3 mm (IRAWAN 683 SP) dengan kandungan protein minimal $30 \%$ Hormon uji yang digunakan pada penelitian ini adalah medroxy progesteron acetat (MPA). Hormon Medroxy progesteron acetat bersifat hidrofilik (Steele et al., 2013) sehingga untuk pencampuran dalam pakan perlu dilarutkan ke dalam kuning telur $0,13 \mathrm{~g} / \mathrm{mL}$. Pengenceran hormon medroxy progesteron menggunakan phosphate buffer saline (PBS) sebanyak $40 \mathrm{~mL} / \mathrm{kg}$ pakan agar mempermudah pencampuran dalam pakan. Larutan medroxy progesteron dengan konsentrasi yang telah ditetapkan, disemprotkan pada pakan lalu diaduk hingga rata dan dikering-anginkan (Permana et al., 2018). Pakan uji diberikan dua kali sehari pada pagi dan sore hari dengan feeding rate $3 \%$ dari bobot biomassa. Pemberian pakan dilakukan secara merata pada setiap sekat agar pakan yang diberikan terdistribusi secara merata.

\section{Parameter Pengujian}

Parameter yang diamati berupa tingkat kematangan gonad (TKG), laju pertumbuhan harian (specific growth rate/SGR), kadar estradiol, fekunditas, egg clutch somatic index (ESI), tingkat sintasan, serta kualitas air selama pemeliharaan.

\section{Perkembangan Gonad}

Pengamatan TKG dilakukan satu minggu sekali dengan mengamati perkembangan gonad secara visual dari warna ovarium yang terletak pada cephalothorax di bagian atas lambung dan hepatopankreas (Reddy et al., 2013).

\section{Konsentrasi Estradiol}

Anal isis estradiol dilakukan dengan cara mengambil sampel hemolim sebanyak $0,3 \mathrm{~mL}$ pada intramuskular kaki jalan ketiga dengan menggunakan syringe ukuran $1 \mathrm{~mL}$ yang telah diberikan antikoagulan EDTA 10\% Sampel disentrifuse dan disimpan pada freezer bersuhu $-20^{\circ} \mathrm{C}$. Pengukuran konsentrasi estradiol dilakukan menggunakan metode Enzyme-Linked Immunosorbent Assay (ELISA).

\section{Laju Pertumbuhan}

Pengamatan laju pertumbuhan menggunakan panjang standar yaitu diukur dari pangkal mata hingga pangkal telson. Pengamatan laju pertumbuhan harian diamati pada hari ke-60 penelitian menggunakan rumus (Effendi, 2004):

$$
\text { SGR }(\%)=\left[\sqrt[n]{\frac{\text { PSt }}{\text { PSo }}}-1\right] \times 100
$$

di mana:

PSo: panjang standar udang awal penelitian ( $\mathrm{mm}$ )

PSt : panjang standar udang akhir penelitian $(\mathrm{mm})$

n : lama waktu pemeliharaan (hari)

\section{Tingkat Sintasan (Survival Rate/SR)}

Tingkat Sintasan merupakan persentase jumlah udang yang hidup pada akhir penelitian dibandingkan jumlah udang awal. Perhitungan SR dilakukan pada akhir penelitian dengan menggunakan rumus:

$$
\mathrm{SR}(\%)=\frac{\mathrm{Nt}}{\mathrm{No}} \times 100
$$

di mana:

SR : survival rate [tingkat sintasan] $(\%$

$\mathrm{Nt}$ : jumlah udang yang hidup di akhir perlakuan (ekor)

No : jumlah udang yang hidup di awal perlakuan (ekor)

\section{Egg clutch somatic index (ESI) dan Fekunditas}

Egg clutch somatic index (ESI) dan fekunditas dihitung pasca pemberian perlakuan. Hal ini dilakukan untuk mengetahui pengaruh pemberian hormon MPA terhadap telur yang dihasilkan. Berat total telur ditentukan dengan cara udang dikeringkan dengan tissue, kemudian telur dikerok dari badan udang dan ditimbang bobot telur dan bobot induk udang. Nilai ESI dihitung dari bo bot telur yang telah dikerok dibagi bobot tubuh udang. Fekunditas dihitung berdasarkan jumlah telur dibagi bobot induk udang. Jumlah telur ditentukan dengan cara pengambilan sebanyak tiga sub sampel yang dihitung secara manual.

\section{Kualitas Air}

Parameter kualitas air yang diukur selama masa penelitian adalah suhu, oksigen terlarut (DO), amonia, nitrit, dan $\mathrm{pH}$.

\section{Analisis Data}

Data yang diperoleh dianalisis dengan menggunakan analisis sidik ragam (ANOVA) menggunakan program SPSS 20, dan jika terdapat pengaruh nyata dilanjutkan dengan uji Duncan.

\section{HASIL DAN BAHASAN}

\section{Tingkat Kematangan Gonad}

Hasil pengamatan perkembangan gonad pada akhir pemeliharaan menunjukkan bahwa pemberian hormon medroxy progesteron memberikan pengaruh nyata 
$(\mathrm{P}<0,05)$ terhadap tingkat kematangan gonad udang galah. Ini terbukti dengan tingginya persentase udang yang belum matang gonad pada perlakuan P-1, P-2, dan P-3 dibandingkan dengan perlakuan kontrol (Gambar 1). Secara berturut-berturut persentase udang yang belum matang gonad pada akhir pemeliharaan pada perlakuan kontrol, P-1, P-2, dan P-3 adalah 57,3 $\pm 6,7 \% 69,4 \pm 7,6 \% 78,6 \pm 6,6 \%$ dan $70,2 \pm 8,5 \%$ Medroxy progesteron acetat (MPA) mengandung progestin sintetik yang bersifat identik seperti progestin alami ikan yang berperan penting pada proses oogenesis (Nagahama \& Yamashita, 2008). Pada mamalia, penggunaan medroxyprogesterone dapat menghambat pematangan pada tikus jantan (Ilyas, 2014; Yurnadi et al., 2011). Penelitian sebelumnya melaporkan bahwa progestin sintetik pada konsentrasi 0,8 ng/L melalui perendaman mampu menghambat reproduksi ikan fathead minnow (Pimephales promelas) dan menghentikan reproduksi pada konsentrasi $85 \mathrm{ng} / \mathrm{L}$ hingga $100 \mathrm{ng} / \mathrm{L}$ (Paulos et al., 2010). Medroxy progesteron memiliki aktivitas androgenik pada benih ikan zebra dan dapat memengaruhi perbedaan jenis kelamin dan spermatogenesis pada konsentrasi $42 \mathrm{ng} / \mathrm{L}$ (Shi et al., 2019). Pemberian MPA dan didogesteron (DDG), serta campuran keduanya melalui perendaman dan dilanjutkan dengan sistem flow-through, sampai mencapai konsentrasi akhir di wadah pemeliharaan sebesar 4,5-4,8 ng/L untuk embrio ikan zebra dan konsentrasi 43-89 ng/L untuk ikan zebra dewasa dapat berpengaruh pada beberapa respons transkripsi dan efek buruk pada reproduksi dan histologi gonad (Zhao et al., 2015).

Hormon medroxyprogesterone acetat (MPA) merupakan progesterone sintesik yang tergolong dalam steroid pada vertebrata yang berperan dalam proses pematangan gonad (Subramoniam, 2011). Peran yang tepat dari hormon steroid pada krustasea masih belum diketahui, tetapi secara pasti telah menunjukkan pengaruhnya terhadap proses vitellogenesis (Swetha et al., 2011). Konsentrasi pemberian hormon MPA harus tepat, karena jika kandungan berlebihan kemungkinan dapat menyebabkan efek negatif. Pada penelitian ini, pemberian MPA dengan konsentrasi $150 \mathrm{mg} / \mathrm{kg}$ pakan cenderung mengalami penurunan persentase udang yang belum matang gonad meskipun tidak berbeda nyata dengan perlakuan pemberian MPA dengan konsentrasi $100 \mathrm{mg} / \mathrm{kg}$ pakan . Seperti halnya pada hormon pertumbuhan yang diberikan pada udang vaname dengan dosis 150; 15; 1,5; 0,15; dan 0,015 mg/L memberikan pertumbuhan terbaik pada dosis $15 \mathrm{mg} / \mathrm{L}$, sedangkan dosis $150 \mathrm{mg} /$ $\mathrm{L}$ media menunjukkan pertumbuhan lebih rendah daripada kontrol (Subaidah, 2012), hal ini menunjukkan bahwa jika hormon pertumbuhan yang ditambahkan berlebih dapat memberikan umpan balik negatif pada kelenjar untuk tidak mensekresi GH.

\section{Konsentrasi Estradiol}

Pengukuran konsentrasi estradiol-17â pada awal penelitian pada setiap perlakuan memiliki nilai

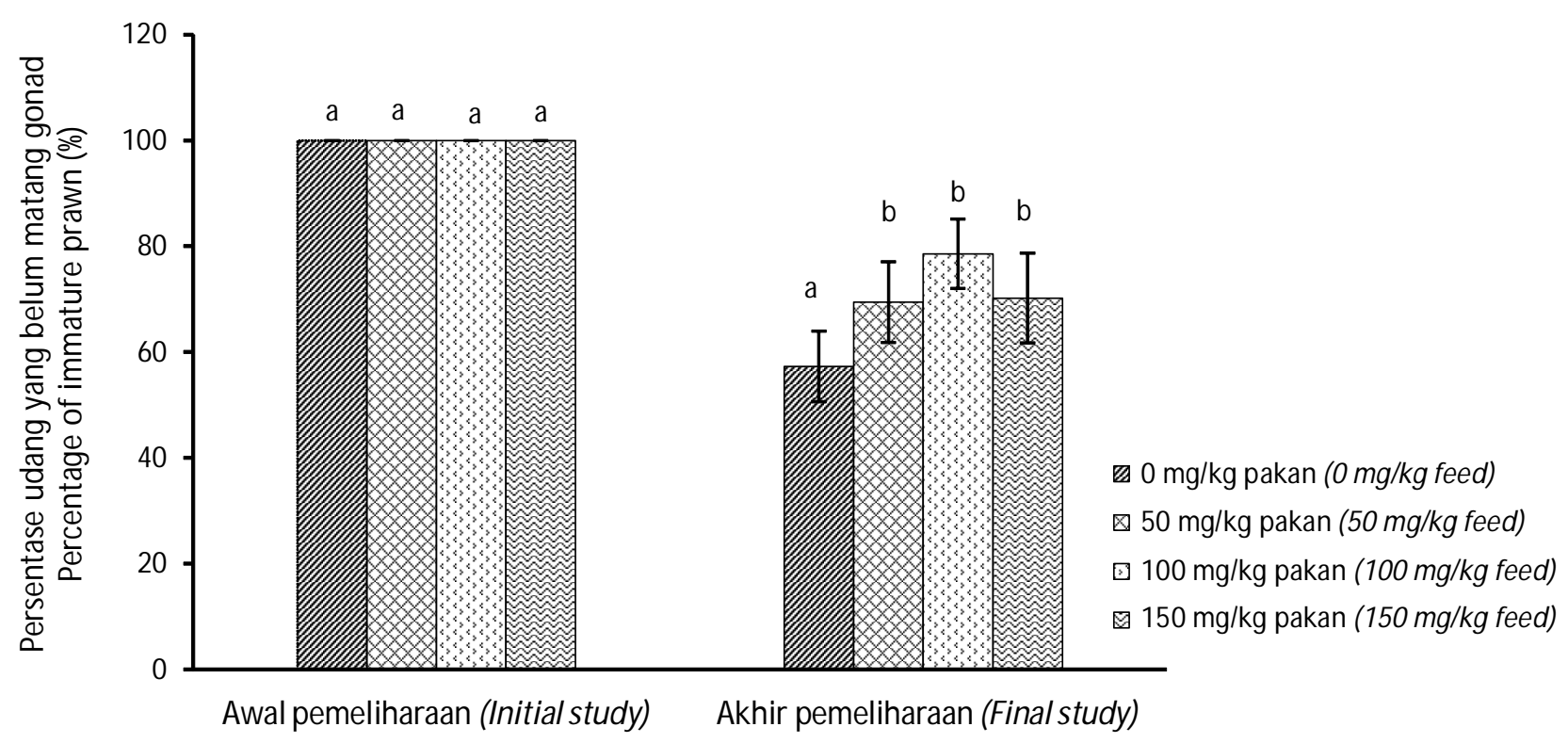

Gambar 1. Persentase udang galah yang belum matang gonad pada awal dan akhir penelitian.

Figure 1. Percentages of immature gonads of giant freshwater prawn at the beginning and end of the study. 
konsentrasi sebesar $56,65 \pm 1,56 \mathrm{pg} / \mathrm{mL}$. Konsentrasi estradiol pada akhir pemeliharaan mengalami peningkatan. Pada akhir pemeliharaan, konsentrasi estradiol perlakuan kontrol sebesar 78,1 $\pm 2,9 \mathrm{pg} /$ $\mathrm{mL}$; lebih tinggi dan berbeda nyata $(\mathrm{P}<0,05)$ dengan konsentrasi estradiol pada perlakuan P-1 $(63,9 \pm 7,6)$, P-2 $(65,2 \pm 2,96)$, dan P-3 $(59,4 \pm 6,0)$ (Gambar 2). Tingginya konsentrasi estradiol pada perlakuan kontrol diduga terkait dengan meningkatnya perkembangan gonad. Estradiol berperan dalam menginduksi sintesis vitelogenin di hati (Dammann et al., 2011; Amaral et al., 2019). Secara umum, hormon reproduksi seperti hormon gonadotropin (GtH) yang ditransportasikan melalui hemolim merangsang kelenjar esterogen yang terletak di dalam gonad untuk mengaktifkan sintesis dan sekresi pelepasan estradiol yang selanjutnya menstimulasi sel hati untuk menyintesis prekursor protein kuning telur vitelogenin (Fingerman, 1997). Aprajita et al. (2014) menyatakan bahwa efek hormon steroid 17â-estradiol dan progesteron pada reproduksi udang galah digunakan sebagai penanda terjadinya vitelogenin. Pada proses vitelogenin, daerah cephalothoracic udang galah diisi dengan ovarium. Proses vitelogenesis terdiri atas dua tahap, yaituimatur dan matur. Pada tahap imatur, warna ovarium transparan dan ketika proses vitellogenesis mencapai tahap matur warna ovarium berubah dari oranye kuning pucat menjadi cokelat gelap (Ganji, 2011). Pada penelitian ini, perlakuan kontrol mempunyai kadar 17â-estradiol paling tinggi, karena pada umumnya pada umur enam bulan udang galah sudah mulai memasuki masa pematangan gonad, berbeda dengan perlakuan pemberian hormon medroxyprogesterone baik P-1, P-2, dan P-3 yang mempunyai konsentrasi estradiol yang lebih rendah. Pengaruh penggunaan hormon MPA terhadap konsentrasi estradiol pada udang galah karena hormon MPA berfungsi untuk menyekresikan hormon luteinizing hormone (LH) dan folicle stimulating hormone (FSH) (Daido et al., 2014). Hormon FSH dan LH merupakan kunci yang mengatur reproduksi (Aizen et al., 2012).

\section{Laju Pertumbuhan}

Perlakuan pemberian hormon MPA melalui pakan pada udang galah betina selama 60 hari berpengaruh terhadap pertumbuhan udang galah. Salah satu indikator berfungsinya sistem metabolisme dalam tubuh adalah adanya pertumbuhan, baik itu pertambahan bobot maupun panjang (Khasani \& Sopian, 2013). Laju pertumbuhan spesifik (SGR) udang galah yang diberi pakan dengan konsentrasi MPA 100 $\mathrm{mg} / \mathrm{kg}$ pakan lebih tinggi dan berbeda nyata $(P<0,05)$ terhadap perlakuan kontrol namun tidak berbeda nyata terhadap perlakuan pemberian hormon dengan konsentrasi $50 \mathrm{mg} / \mathrm{kg}$ pakan dan $150 \mathrm{mg} / \mathrm{kg}$ pakan (Tabel 1). Perlakuan pemberian MPA konsentrasi 50 $\mathrm{mg} / \mathrm{kg}$ tidak berbeda nyata dengan kontrol. Hal yang sama terjadi pada pemberian M PA dengan konsentrasi tertinggi yaitu $150 \mathrm{mg} / \mathrm{kg}$ pakan. Hal ini diduga karena persentase udang yang belum matang gonad cenderung menurun sehingga berpengaruh terhadap nilai SGR udang. Nilai SGR pada perlakuan kontrol, P1, P-2, dan P-3 berturut-turut adalah 0,20 $\pm 0,0128 \%$

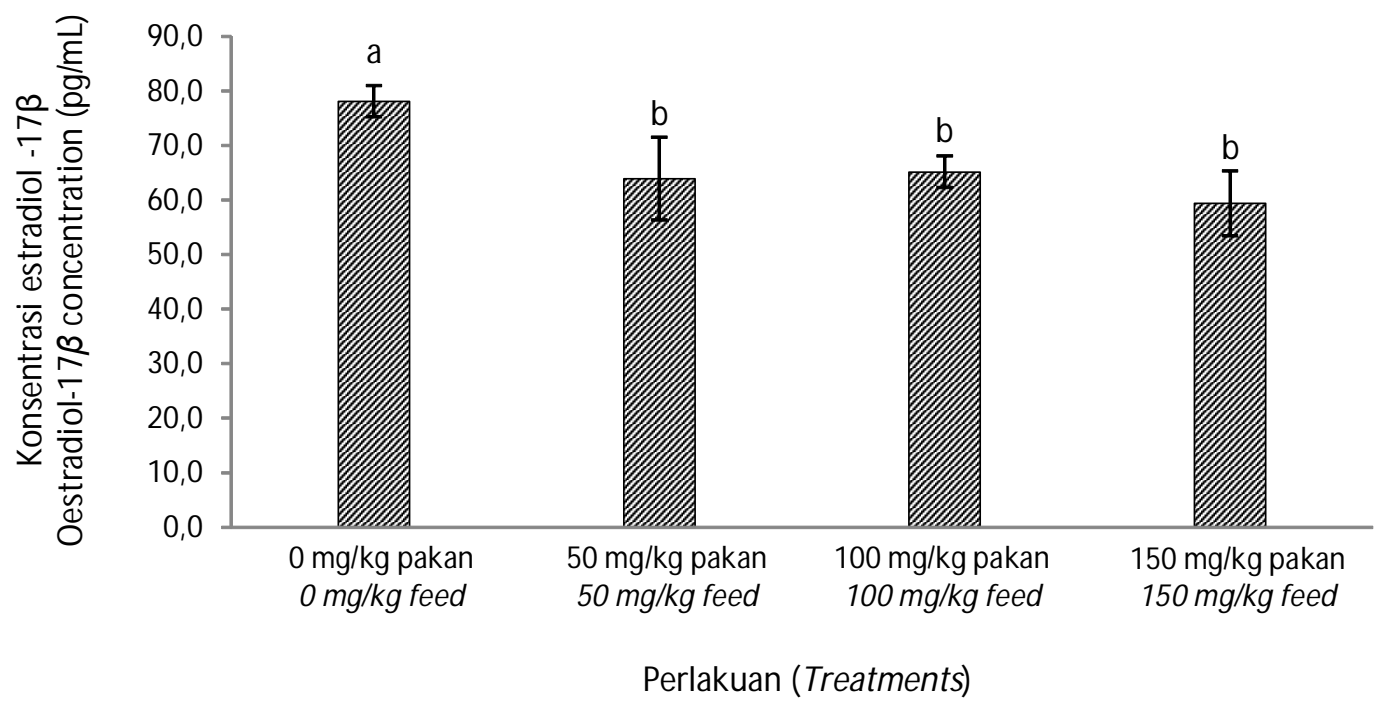

Gambar 2. Konsentrasi estradiol dalam hemolim udang galah pada setiap perlakuan pada akhir pemeliharaan.

Figure 2. Estradiol concentrations of giant freshwater prawn's hemolymph in each treatment at the end of the study. 
Tabel 1. Laju pertumbuhan spesifik (SGR), sintasan (SR), fekunditas, dan egg clutch somatic index (ESI) udang galah yang diberi hormon MPA dengan konsentrasi berbeda

Table 1. Specific growth rate (SGR), survival rate (SR), fecundity, and egg clutch somatic index (ESI) of giant freshwater prawn treated with MPA hormone with different concentrations

\begin{tabular}{lcccc}
\hline \multicolumn{1}{c}{$\begin{array}{c}\text { Parameter } \\
\text { Param eters }\end{array}$} & \multicolumn{4}{c}{$\begin{array}{c}\text { Konsentrasi hormon (mg/kg pakan) } \\
\text { Hormone concentrations (m } / \mathbf{k g} \text { feed) }\end{array}$} \\
\cline { 2 - 5 } & $\mathbf{0}$ & $\mathbf{5 0}$ & $\mathbf{1 0 0}$ & $\mathbf{1 5 0}$ \\
\hline $\begin{array}{l}\text { Panjang standar awal } \\
\text { Initial standard length (mm) }\end{array}$ & $58.50 \pm 1.1^{\mathrm{a}}$ & $58.73 \pm 1.39^{\mathrm{a}}$ & $59.53 \pm 0.79^{\mathrm{a}}$ & $58.86 \pm 1.03^{\mathrm{a}}$ \\
$\begin{array}{l}\text { Panjang standar akhir } \\
\text { Final standard length (mm) }\end{array}$ & $66.21 \pm 1.09^{\mathrm{b}}$ & $67.07 \pm 1.98^{\mathrm{ab}}$ & $68.80 \pm 1.54^{\mathrm{a}}$ & $66.86 \pm 0.89^{\mathrm{ab}}$ \\
$\begin{array}{l}\text { Laju pertumbuhan spesifik } \\
\text { Specific growth rate (\%) }\end{array}$ & $0.20 \pm 0.01^{\mathrm{b}}$ & $0.21 \pm 0.01^{\mathrm{ab}}$ & $0.24 \pm 0.02^{\mathrm{a}}$ & $0.22 \pm 0.01^{\mathrm{ab}}$ \\
$\begin{array}{l}\text { Sintasan } \\
\text { Survival rate (\%) }\end{array}$ & $100 \pm 0^{\mathrm{a}}$ & $97.5 \pm 5^{\mathrm{a}}$ & $100 \pm 0^{\mathrm{a}}$ & $95 \pm 10^{\mathrm{a}}$ \\
$\begin{array}{l}\text { Fekunditas (butir/g induk) } \\
\text { Fecundity (egg/g broodstrock) }\end{array}$ & $961 \pm 66^{\mathrm{a}}$ & $985 \pm 217^{\mathrm{a}}$ & $719 \pm 111^{\mathrm{a}}$ & $977 \pm 83^{\mathrm{a}}$ \\
Egg clutch somatic index (ESI) & $0.10 \pm 0.00^{\mathrm{a}}$ & $0.11 \pm 0.01^{\mathrm{a}}$ & $0.08 \pm 0.02^{\mathrm{a}}$ & $0.13 \pm 0.02^{\mathrm{a}}$ \\
\hline
\end{tabular}

Keterangan: Huruf superskrip berbeda pada baris yang sama adalah berbeda nyata secara statistik $(P<0,05)$

Note: Different superscript letters in the same row show significant differences $(P<0.05)$

$0,21 \pm 0,0084 \% 0,24 \pm 0,024 \% 0,22 \pm 0,0085 \%$ Pola hubungan tingkat kematangan gonad dengan pertumbuhan (SGR) udang dapat dilihat pada Gambar 3. Perlakuan yang mempunyai persentase udang yang belum matang gonad tinggi mempunyai pertumbuhan yang lebih tinggi dan sebaliknya perlakuan yang mempunyai persentase udang yang belum matang gonad rendah mempunyai laju pertumbuhan yang lebih rendah juga. Hal ini sesuai dengan pernyataan Cavalli et al. (2001) bahwa penggunaan energi dari pakan yang diharapkan untuk pertumbuhan pada udang galah betina dewasa digunakan untuk pembentukan telur atau untuk aktivitas reproduksi. Pakan yang dikonsumsi udang secara fisiologis akan dicerna dan digunakan untuk pertumbuhan somatik. Jika udang mengalami maturasi, maka energi dari pakan tersebut akan terbagi untuk reproduksi, akibatnya pertumbuhan somatik terganggu sehingga ukuran udang menjadi lebih kecil dari yang diharapkan (Franco et al., 2006).

Tabel 1 menunjukkan bahwa pemberian hormon MPA melalui pakan tidak berpengaruh terhadap fekunditas, ESI dan tingkat sintasan $(P>0,05)$. Induk betina udang galah hasil pemuliaan dapat menghasilkan fekunditas yang tinggi, yaitu 10.000-60.000 butir telur per ekor (Luan et al., 2012). Hasil penelitian Cavalli et al. (2001) menunjukkan fekunditas udang galah berkisar antara $1.388 \pm 239$ sampai dengan $1.519 \pm$ 193 butir/g induk. Selama pemeliharaan sintasan relatif tinggi jika dibandingkan dengan pemberian hormon MPA melalui injeksi yaitu hanya sebesar $20 \% 46,67 \%$
(Wijaya et al., 2020). Hal ini karena perlakuan pemberian hormon melalui pakan tidak menyebabkan stres pada udang. Selain itu, sistem pemeliharaan yang menggunakan sekat mampu meminimalkan kanibalisme yang biasa terjadi pada udang galah. Kanibalisme akan terjadi pada saat udang mengalami moulting yaitu pada saat bergantinya cangkang/kulit luar udang sehingga badan udang menjadi lembek sehingga menjadi mangsa bagi udang galah lainnya. Fenomena moulting terjadi karena beberapa faktor yaitu pertumbuhan, reproduksi, dan stres (Hess, 2014). Efektivitas aplikasi hormon pada udang lebih efektif melalui teknik injeksi dibandingkan secara oral, akan tetapi cara injeksi membutuhkan keahlian tersendiri terutama dalam meminimalkan tingkat stres udang selama injeksi dilakukan. Dengan kata lain, aplikasi hormon secara oral pada skala komersil diduga lebih efisien karena tekniknya mudah dan tidak memberikan dampak stres pada induk, meskipun secara umum pemberian hormon secara oral diperlukan dosis yang lebih tinggi (Laining et al., 2015; Alimuddin et al., 2014). Namun demikian, aplikasi pemberian hormon dengan teknik oral yang dilakukan melalui pakan buatan atau pakan alami yaitu dengan cara mencampurkan hormon pada pakan telah menjadi alternatif dalam peningkatan performa pada budidaya ikan atau udang. Teknik oral melalui pakan buatan telah banyak dilakukan pada ikan dan udang (Subaidah, 2013; Alimuddin et al., 2014; Permana et al., 2018; Kurniawan et al., 2017). 


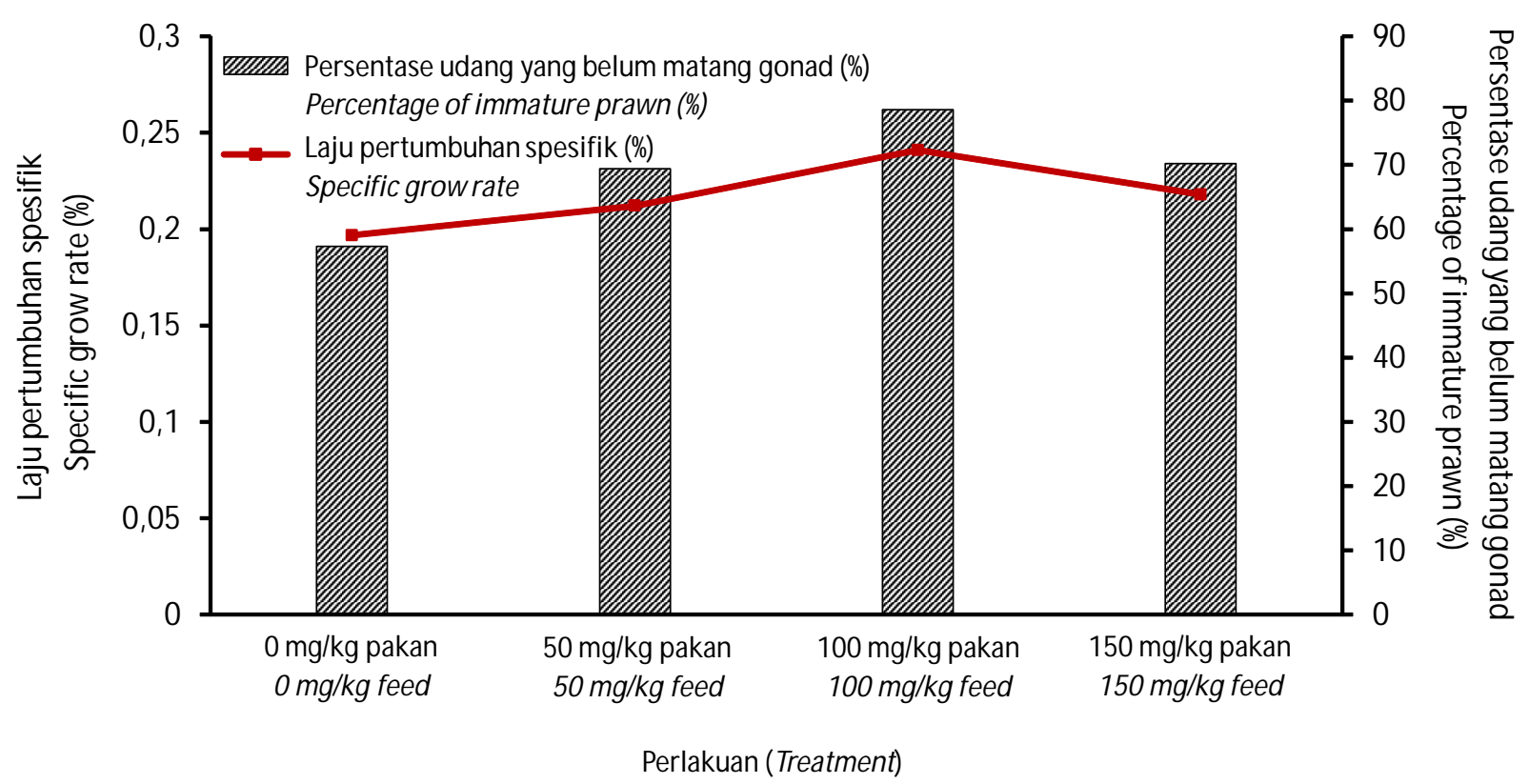

Gambar 3. Pola hubungan kematangan gonad dengan pertumbuhan udang galah.

Figure 3. The pattern of relations between gonad maturity on growth.

Tabel 2. Kualitas air media pemeliharaan selama pemeliharaan

Table 2. Water quality of grow-out media during the rearing period

\begin{tabular}{|c|c|c|c|c|c|}
\hline \multirow[b]{2}{*}{$\begin{array}{l}\text { Perlakuan } \\
\text { Treatments }\end{array}$} & \multicolumn{5}{|c|}{ Parameter kualitas air (Water quality parameters) } \\
\hline & $\begin{array}{c}\text { Suhu } \\
\text { Temperature } \\
\text { ('C) }\end{array}$ & pH & $\mathrm{DO}(\mathrm{mg} / \mathrm{L})$ & $\mathrm{NH}_{3}(\mathrm{mg} / \mathrm{L})$ & $\mathrm{NO}_{2}$ (mg/L) \\
\hline 0 mg MPA/kg pakan (0 mg MPA/kg feed ) & $28-30$ & $7.97-8.80$ & $5.9-6.2$ & $0.048-0.1772$ & $0.0358-0.1387$ \\
\hline $50 \mathrm{mg}$ MPA/kg pakan (50 mg MPA/kg feed) & $28-30$ & $7.55-8.44$ & $4.7-8.1$ & 0.0377-0.1206 & $0.0240-0.1195$ \\
\hline $100 \mathrm{mg}$ MPA/kg pakan (100 mg MPA/kg feed) & $28-30$ & 8.03-8.35 & 5.1-7.7 & $0.0414-0.1561$ & $0.0169-0.1613$ \\
\hline $150 \mathrm{mg}$ MPA/kg pakan (150 mg MPA/kg feed ) & $28-30$ & $8.16-8.80$ & $4.7-7.7$ & $0.039-0.179$ & $0.0371-0.1812$ \\
\hline $\begin{array}{l}\text { Standar baku mutu (Quality standard) } \\
\text { (New \& Valenti, 2000) }\end{array}$ & $25-32$ & $7-8.5$ & 3-7 & $0.1-0.3$ & $0.1-0.7$ \\
\hline
\end{tabular}

\section{Kualitas Air}

Selain pakan, kualitas air merupakan faktor yang dapat memengaruhi kehidupan udang galah. Pada penelitian ini, hasil pengamatan kualitas air selama pemeliharaan menunjukkan bahwa kisaran suhu harian, $\mathrm{pH}, \mathrm{DO}$, amonia $\left(\mathrm{NH}_{3}\right)$, dan nitrit $\left(\mathrm{NO}_{2}\right)$ pada media uji berada dalam kisaran optimal dan tidak mengalami fluktuasi yang signifikan.

\section{KESIMPULAN}

Pemberian hormon medroxy progesteron acetat melalui pakan berpengaruh terhadap performa reproduksi dan pertumbuhan udang galah betina. Konsentrasi MPA 50-150 mg/kg pakan dapat menghambat pematangan gonad udang galah betina dan konsentrasi MPA sebesar100 mg/kg pakan memberikan pertumbuhan terbaik. Dengan demikian dosis MPA $100 \mathrm{mg} / \mathrm{kg}$ pakan dapat direkomendasikan untuk diaplikasikan pada pemeliharaan udang galah.

\section{UCAPAN TERIMA KASIH}

Terima kasih yang sebesar-besarnya disampaikan kepada Kepala Balai Riset Pemuliaan Ikan dan Dr. Ikhsan Khasani, S.Si., M.Si. atas bimbingan teknisnya dan tim komoditas udang galah atas bantuannya selama pelaksanaan penelitian ini.

\section{DAFTAR ACUAN}

Aizen, J., Kobayashi, M., Selicharova, I., Sohn, Y.C., Yoshizaki, G., \& Levavi-Sivan, B. (2012). Steroidogenic response of carp ovaries to piscine FSH and LH depends on the reproductive phase. General and Comparative Endocrinology, 178, 28-36. 
Alimuddin, Handoyo, B., \& Utomo, N.B.P. (2014). Efektivitas pemberian hormon pertumbuhan rekombinan ikan kerapu kertang (Epinephelus lanceolatus, Bloch 1790) melalui perendaman dan oral terhadap pertumbuhan elver ikan sidat (Anguilla bicolor bicolor ). Jurnal Iktiologi Indonesia, 14(3), 179-189.

Amaral, J.S., Venturieri, R.L., \& Moreira, R.G. (2019). Gonadal steroids and energy availability during ovarian maturation stages of the Amazonian pirarucu Arapaima gigas (teleostei: Osteoglossidae) in the wild. Comp. Biochem. Physiol. part A: Molecul Integrat Physiol., 230, 106-114.

Aprajita, K., Pandey, A.K., Singh, R., \& Chauhan, U.K. (2014). Reproductive endocrinal regulation in decapod crustaceans/: A review. J. Ecophysiol. Occup. Hlth., 14(1\&2), 55-65.

Cavalli, O.C., Lavens, P., \& Sorgeloos, P. (2001). Reproductive performance of Macrobrachium rosenbergii females in capacity. Journal of the World Aquaculture Society, 32(1), 60-67.

Daido, I., Tahir, A.M., \& Chalid, T. (2014). Changes of body mass index and lipi profile in injectable depot medroxyprogesterone acetate and levonorgestrel implant acceptors. Indonesian Journal of Obstetrics and Gynecology, 2(3), 1-15.

Dammann, A., Shappell, N., Bartell, S., \& Schoenfussa, H. (2011). Comparing biological effects and potencies of estrone and 17 â-estradiol in mature fathead minnows Pimephales promelas. Aquat. Toxicol., 105, 559-568.

Effendi, I. (2004). Pengantar akuakultur. Depok (ID): Penebar Swadaya.

FAO. (2020). The State of World Fisheries and Aquaculture. Sustainability in Action.Rome. DOI: $10.4060 / c a 9229$ en.

Fingerman, M. (1997). Roles of neurotransmitters in regulating reproductive hormone release and go nadal maturation in decapods crustaceans. Invertebr.Reprod. Dev., 31(1-3), 47-54.

Franco, A.R., Ferreira, J.G., \& Nobre, A.M. (2006). Development of a growth model for penaeid shrimp. Aquaculture, 259(1-4), 268-277. DOI: 10.1016/j. aquaculture.2006.05.051.

Ganji, P.C.N. (2011) A Review on reproductive regulators in decapods crustacean. The Journal of Exp. Biol., 214, 3-16.

Hess, W.N. (2014). Actors influencing moulting in the crustacean. Crangon armillatus armillatus. Marine Biological Laboratory, 81(2), 215-220.
Ilyas, S. (2014). Effect of methanolic momordica charantia seed extract and depot medroxyprogesterone acetate (DMPA) to quantity and quality of rat sperm. International Journal of Pharm Tech. Research, 6(6), 1817-1823.

Jayasankar, P. (2018). Present status of freshwater aquaculture in India: A review. Indian J. Fish., 65, 157-165.

Khasani, I., Krettiawan, H., Sopian, A., \& Anggraeni, F. (2018). Selection response and heritability of growth traits of giant freshwater prawn (Macrobrachium rosenbergii) in Indonesia. AACL Bioflux, 11(6), 1688-1695.

Khasani, I. \& Sopian, A. (2013). Pertumbuhan dan sintasan benih udang galah (Macrobrachium rosenbergii de Man) pada pendederan berbasis sistem heterotrof dengan padat tebar berbeda. Jurnal Riset Akuakultur, 8(3), 373-382.

Krettiawan, H. \& Anggraeni, F. (2015). Evaluasi Potensi Seleksi Individu Secara Simultan Berdasarkan Karakter Pertumbuhan dan Kematangan Kelamin Udang Galah Betina (Macrobrachium rosenbergii de Man, 1879). Prosiding Forum Inovasi Teknologi Akuakultur, hlm. 75-81.

Kurniawan, A., Basuki, F., \& Nugroho, R.A. (2017). Pengaruh pemberian rekombinan hormon pertumbuhan $(\mathrm{rGH})$ melalui metode oral dengan interval waktu yang berbeda terhadap pertumbuhan dan kelulushidupan benih ikan bawal air tawar (Colossoma mcroponum). Journal of Aquaculture Management and Technology, 6(3), 20-29.

Laining, A., Lante, S., \& Usman. (2015). Induksi pematangan gonad dan peningkatan tingkat pembuahan telur induk udang windu, Penaeus monodon melalui rangsangan hormonal tanpa ablasi mata. Jurnal Riset Akuakultur, 10(1), 61-68. DOI: 10.15578/jra.10.1.2015.61-68.

Luan, S., Yang, G., Wang, J., Luo, K., Zhang, Y., Gao, Q., Hu, H., \& Kong, J. (2012). Genetic parameters and response to selection for harvest body weight of the giant freshwater prawn Macrobrachium rosenbergii. Aquaculture, 362-363, 88-96.

Nagahama, Y. \& Yamashita, M. (2008). Regulation of oocyte maturation in fish. Development Growth and Differentiation, 50(SUPPL. 1). DOI: 10.1111/ j.1440-169X.2008.01019.x.

New, M.B. \& Valenti, W.C. (2000). Freshwater prawn culture: The farming of Macrobrachium rosenbergii, Blackwell Science. DOI: 10.1002/ 9780470999554. 
Paulos, P., Runnalls, T.J., Nallani, G., La Point, T., Scott, A.P., Sumpter, J.P., \& Huggett, D.B. (2010). Reproductive responses in fathead minnow and Japanese medaka following exposure to a synthetic progestin, Norethindrone. Aquatic Toxicology, 99(2), 256-262. DOI: 10.1016/ j.aquatox.2010.05.001.

Permana, A. Alimuddin, Hadie, W., Priyadi, A., \& Ginanjar, R. (2018). Pengaruh Pemberian hormon pertumbuhan rekombinan dengan metode yang berbeda terhadap pertumbuhan benih ikan botia (Chromobotia macracanthus). Jurnal Riset Akuakultur, 13(2), 123-130. DOI: 10.15578/ Jra.13.2.2018.123-130.

Ranjeet, K. \& Kurup, B.M. (2011). Density dependant variations on the production and population structure of Macrobrachium rosenbergii reared in the wetland polders of South India. Braz. J. Aquat. Sci. Technol., 5, 55-62.

Reddy, C., Reddy, D.C., \& Kalarani, V. (2013). Changes in the ovarian vitellogenin levels during ovarian cycle in the giant freshwater prawn, Macrobrachium rosenbergii. Weekly Science Research Journal, 1(12), 1-15. DOI: 10.9780/23217871/1122013/35.

Shi, W., Ma, D., Jiang, Y., Xie, L., Zhang, J., Huang, G., Chen, H., Hou, L., Liu, Y., \& Ying, G. (2019). Medroxyprogesterone acetate affects sex differentiation and spermatogenesis in zebra fish. Aquatic Toxicology, p. 70-76. DOI: 10.1016/ j.aquatox.2019.04.014.

Steele, W.B., Garcia, S.N., Huggett, D.B., Venables, B.J., Barnes, S.E., \& Point, T.W.L. (2013). Tissuespecific bioconcentration of the synthetic steroid hormone medroxyprogesterone acetate in the common carp Cyprinus carpio. Environmental Toxicology and Pharmacology, 36, 1120-1126.
Subaidah, S., Carman, O., Sumartadinata, K., Sukenda, \& Alimuddin. (2012). Respons pertumbuhan dan ekspresi gen udang vaname, Litopenaeus vannamei setelah di rendam dalam larutan hormon pertumbuhan rekombinan ikan kerapu kertang. Jurnal Riset Akuakultur, 7(3), 359-369.

Subaidah, S. (2013). Growth response and immune of white shrimp Litopenaeus vannamei on administration of recombinant giant grouper growth hormone. Ph.D. Tesis Institut Pertanian Bogor. Bogor, $143 \mathrm{hlm}$.

Subramoniam, T. (2011). Mechanisms and control of vitellogenesis in crustaceans. Fish. Sci., 77, 1-21.

Swetha, C.H., Sainath, S.B., Reddy, P.R. \& Reddy, P.S. (2011). Reproductive endocrinology of female crustaceans: perspective and prospective. Journal of Marine Science: Research \& Development. S:3. DOI: 10.4172/2155-9910.S3-001.

Wijaya, M., Sudrajat, A.O., \& Imron. (2020). Reproductive and growth performances in female giant freshwater prawn following inhibition of gonadal maturation using dopamine and medroxyprogesterone hormone. Jurnal Akuakultur Indonesia, 19(1), 10-18. DOI: 10.19027/jai.19.1.1018.

Yurnadi, A.Y., Suryandari, D.A., \& Moeloek, N. (2011). Combination of depot medroxyprogesterone acetate and Javanese long pepper extract on body weight, hematology, and blood biochemistry as a safe contraception model. Makara Sains, 15(2), 155-162.

Zhao, Y., Castiglioni, S., \& Fent, K. (2015). Synthetic progestins medroxyprogesterone acetate and dydrogesterone and their binary mixtures adversely affect reproduction and lead to histological and transcriptional alterations in zebra fish (Danio rerio). Environmental Science and Technology, 49, 4636-4645. DOI: 10.1021/es505575v. 